\title{
CHROMIUM REDUCTION USING BACTERIAL BIOFILMS
}

\author{
Madhumala Y \\ Department of Biotechnology \\ Basaveshwar Engineering College, Bagalkot, Karnataka, India \\ Veena S Soraganvi \\ Department of Civil Engineering \\ Basaveshwar Engineering College, Bagalkot, Karnataka, India \\ Nikhita H Ingalagi \\ Department of Biotechnology \\ Basaveshwar Engineering College, Bagalkot, Karnataka, India
}

\begin{abstract}
Biofilms are the aggregates of the bacterial colonies which are found to be the friends and foes to the mankind. Biofilms of bacteria can be employed in not only removal of organic waste but can also can be used in treatment of hexavalent chromium containing waste, an element which is found to be carcinogenic, mutagenic and irritative in nature. The organism forming biofilm is isolated from tannery effluent and is quantitatively and qualitatively analysed by using tube assay and microtiter plate assay. The isolate was identified by using 16srRNA technology with the help of barcode institute Aurangabad it is identified as Bacillus vietnamiensis .Bacillus vietnamiensis culture was able to reduce almost $100 \%$ of $500 \mathrm{mg} / \mathrm{lt}$ of hexavalent chromium at $6 \mathrm{pH}$ and tempratureof $35^{\circ} \mathrm{C}$ under normal areobic conditions.Optimisation experiments proved temperature $35^{\circ} \mathrm{C}$ and $\mathrm{pH} 6$ is more favourabl e for bacterial growth and as well as reductionprocess. The bacteria is found to be more potent as it is obtained from the indigenous source and found to be very efficient in reduction of hexavalent chromium.
\end{abstract}

Keywords - EPS-exopolysaccharide, PBS- phosphate buffered saline, QS- quorum sensing, TSB- Trypticase soya broth, AHL-acylhomoserine lactones, AI auto inducers.

\section{INTRODUCTION}

Bacterial biofilms are the architectural aggregations growing almost on every surface forming complex communities [1]. Biofilms are found since evolution began on the earth. In medical microbiology, biofilms are studied for chronic infections. Biofilms normally colonize on different household surfaces and due to low rate of disinfection practices and improper sanitization of different products leads to prevalence of illness by pathogens. The antibiotic era has proved to be efficient in curing of different bacterial diseases as earlier people used to die of pneumonia and other different acute infections [2]. Biofilm is found to comprise of thoroughly structured matrix surrounded by their communities [3]. The cells of Biofilm produce their genes with different Pattern from their Plank tonic counterparts [4]. Pure cultures of biofilm producing bacteria and consortium in the nature presents their cell growth in the form of microcolonies enclosed in a specialized matrix. The specialized structure of biofilms can be observed by scanning confocal laser microscopy which helps to differentiate cells-cells signals and their cellular specialization [4]. The $\mathrm{Cr}(\mathrm{VI})$ reduction by bacteria is a wonderful mechanism which shows resistance of organism to $\mathrm{Cr}(\mathrm{VI})$. It penetrates the cell membrane of bacteria as it is a strong oxidizing agent. Bacteria Resistance of $\mathrm{Cr}$ (VI) is based on presence of plasmid and the sensitive cells cannot accumulate $\mathrm{Cr}$ (VI) as resistant cells [5].

\section{BIOFILM STRUCTURE AND DIFFERENTIATION}

\section{A. Biofilm Formation}

Biofilm formation is mainly classified as 3 main phases early, intermediate and matures [6]. In the earlier phase the free planktonic cells move through the surface using their flagella and go on aggregating to form the mass growth. The stages of growth of biofilms are depicted in (Figure 1 which is as follows). Phase 1: Primary adherence of the cells to the surface, Phase 2: Exopolysaccharide production of cells results in attachment of cells which is irreversible in nature, Phase 3: Results in primary development of biofilm structure, Phase 4: Maturation of biofilm structure and Phase 5: Moving and Scattering of the single cells from the biofilm layer. The figure 1 indicates the phases of growth production of Bacillus [7].

The interaction among the microbes and its substratum results in the production of cells of monolayer. Some bacteria 


\section{International Journal of Engineering Applied Sciences and Technology, 2020 \\ Vol. 5, Issue 5, ISSN No. 2455-2143, Pages 198-202 \\ Published Online September 2020 in IJEAST (http://www.ijeast.com)}

are not resistant to antibiotics and thus can be successfully used in treatment. It is necessary to analyze peri operative antibiotic prophylaxis. [2, 8]. The EPS produced during this stage is found around the bacterial microcolonies, it consists of polymers, polysaccharides and water molecules bound within the capsules [10]. The polymers are secreted by biofilms matrix which absorbs nutrients, metabolic products and intracellular products [11-13].

Quorum sensing mechanism [14] is used to study the various phases of development of biofilm. It helps to study the mechanism of production of biofilm, release of the cells and detection of chemical signaling molecules it also regulates the gene expression within the cells based on the density gradient $[15,16]$ well defined groups of signaling found in bacteria are oligopeptides, acylhomoserine lactones and auto inducers [16]. Oligopeptides are the molecules used by gram positive bacteria for communication $[17,18]$ while gram negative ones use AHLs but AI -2 is found to be universal signaling molecules used to communicate among the inter and intraspecies [16].

Boles and Horswill have studied QS in Staphylococcus aureus Agr, which helps in sensing the systems controls in switching between the free cells, biofilm layer [19].

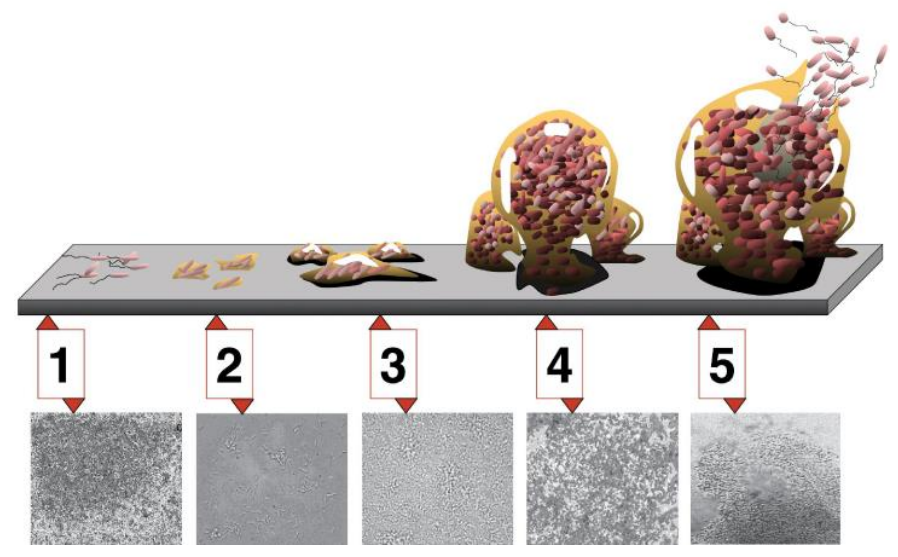

Fig 1. Different phases of biofilm development [7].

\section{B. Role of surfaces in the origin of cells}

Prokaryotic cells have mainly existed from a membrane consisting of protein and nucleic acid with other Cytoplasmic contents in a highly structured membrane. The bacterial cells which randomly float or swim have also evolved in the studies. Biofilms operate mainly on well structured and harmonized community, which consists of prokaryotic with membranes of specific functions [20]. Generally the crystals exhibit high levels of orders, clay show extreme structure aeries of alternating bands of various charges and composition. Caims-Smith [4] has compared the arrangement of enzyme molecules which is having the structure similar to clay molecules. The Physical proximity from one cell to another cell gives a selective pressure for creating complex interaction among the earlier communities.

\section{MATERIALS AND METHODS}

\section{A. Bacterial Strains and Growth Condition}

The bacteria were isolated from chromium contaminated sites. Here the tannery effluent was taken as the sample for isolating the indigenous bacteria. The sample was incubated into the nutrient agar plates and further, the colonies obtained on the plates were incubated on NA plates containing $1000 \mathrm{mg}$ of $\mathrm{K}_{2} \mathrm{Cr}_{2} \mathrm{O}_{7}$. The organism which was able to grow and form a confluent colony was further tested for biofilm production. The bacterium was streaked on NB plates and incubated for 24 hours at $37^{\circ} \mathrm{C}$ from a preserved culture. The organisms were grown in different temperatures of $20^{\circ} \mathrm{C}, 30^{\circ} \mathrm{C}, 35^{\circ} \mathrm{C}$, and $40^{\circ} \mathrm{C}$ to analyze their optimum growth. In other plates, colonies were used to inoculate $5 \mathrm{ml}$ of nutrient broth (NB) in phosphate-buffered saline (PBS) which was incubated at $37^{\circ}$ $\mathrm{C}$ for 24 hours. The grown preculture for 18 hours was further used for centrifugation (100ml NB in PBS). The bacteria which were taken from centrifugation was further harvested and washed with sterile Millipore-Q water twice [2] further the biofilm assay was carried out.

\section{GROWTH AND ANALYSIS OF BIOFILM LAYERS}

Production of bacterial biofilms can be examined \& studied by variety of systems. The primary stages of biofilm formation of different bacteria help to know the pattern of aggregation. The static assays are helpful in observing the preliminary stages of biofilm formation which can be detected within 60 minutes duration [26]. To study the cell death in biofilm which are treated with antimicrobial agents' colony based biofilm is very essential.

\section{A. Colony Biofilm Assay}

Biofilm colonies are cultured on a semipermeable membrane on agar plates [27] Fig 2 indicates the growth of biofilm on the agar plate. These type of biofilms can be used for mass growth by providing the essential nutrients on a fresh agar plates. Biofilms with different carbon source can be cultivated on the agar plate. These biofilm colonies can be used in studying the antibiotic resistant properties of the bacterial cells. It provides an example to study the effect antibiotics on the cells [26].

Different types of biofilms system indicate the adherence of bacterial cells on the surface even in the liquid medium. The above mentioned assay is one among the best procedures, to study the adherence and aggregation of bacterial cells. These biofilms are developed for meeting nutritional needs and removal of wastes for analyzing the assays. The organism can be either grown in plants or broth [27]. An advantage of biofilm growing on plate is that they are derived from clonal growth of original population of bacteria which are deposited on the substratum. in liquid media the bacteria which are motile may move from aggregates of cells [23]. The bacteria in the biofilms have very less ability to detach and move or drift from the biofilm layer. Thus, biofilm colonies are useful in visualizing the effects of antimicrobial agents though there 
is change in cell ratio; it is attributed to cell death rather than detachment.

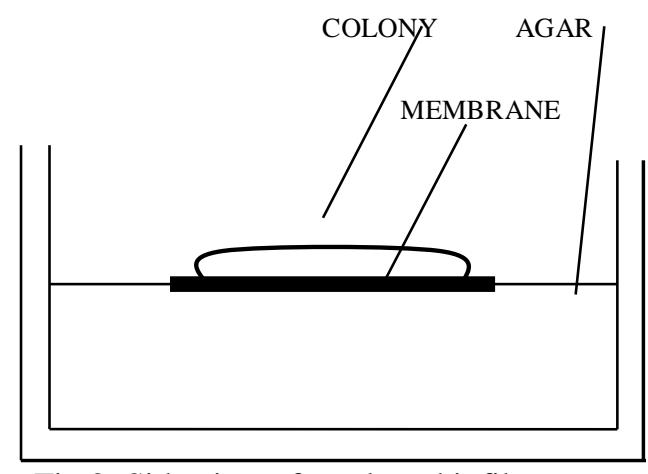

Fig 2: Side view of a colony biofilm assay

\section{B. Tube Assay}

Qualitative assessed biofilm development was done by the tube assay method [30]. Trypticase soya broth (TSB) with an amendment of sucrose (5\%) in which bacteria were grown and kept for incubation for 24 hours at $37^{\circ} \mathrm{C}$ at both rotary and static conditions. The broth from the tubes was decanted, dried, and was stained with $0.1 \%$ of crystal violet. By observation of the film on the wall and base of the tube, the biofilm formation was confirmed. Here liquid interface will not indicate the biofilm formation [30].

\section{Microtiter plate assay}

Quantitative estimation of biofilm formation was done by microtiter plate assay. The dilution of grown cultures was done by 100 times. In the 96 well of Elisa plate $200 \mu \mathrm{l}$ of cultures were added. In static and stained condition with $0.1 \%$ (w/v) solution of crystal violet, the cultures were put in a triplicate and were further incubated for 24 hours at different time intervals of $20{ }^{\circ} \mathrm{C}, 30^{\circ} \mathrm{C}, 35^{\circ} \mathrm{C}$ and $40^{\circ} \mathrm{C}$ to observe the growth of biofilms. Using $96 \%$ of ethanol excess stain was washed off and plates dried and using the micro ELISA auto reader Optical density (OD) wavelength was measured for 570nm [30].

\section{Analyzing the growth of biofilm}

The optimization process is carried out to enhance the growth of the organism. The selected parameters used here are temperature and $\mathrm{pH}$. The experiment is to analyze the effect of temperature on the growth of the organisms and to determine the optimum temperature in which the organisms can be grown. $5 \%$ of isolated culture is inoculated into the $200 \mathrm{ml}$ of TSB medium and kept for incubation at $20^{\circ} \mathrm{C}, 30^{\circ} \mathrm{C}, 35^{\circ} \mathrm{C}$, $40^{\circ} \mathrm{C}$ temperature, and $\mathrm{OD}$ is measured at $570 \mathrm{~nm}$ at a time interval of 24 hours. To determine the optimum $\mathrm{pH}$ favorable for the growth of the organism the culture is inoculated into the $200 \mathrm{ml}$ of TSB medium with varying $\mathrm{pH}$ of $5 \mathrm{pH}, 6 \mathrm{pH}$, $7 \mathrm{pH}, 8 \mathrm{pH}, 9 \mathrm{pH}$, and later the OD of biofilms is measured at $570 \mathrm{~nm}$ at a time interval of 24 hours.
The classification was done according to absorbance as weakly adherent (week biofilm producer), $0.10 \geq A>0.06$; moderately adherent (moderate biofilm producer), $0.20 \geq \mathrm{A}>0.16$; and strongly adherent (strong biofilm producer), $\mathrm{A}>0.24$.

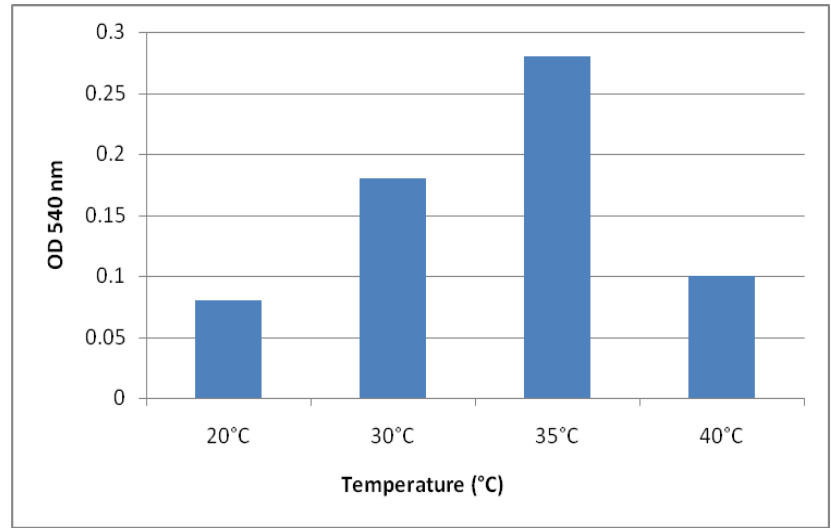

Figure 3: Temperature optimization of biofilm production

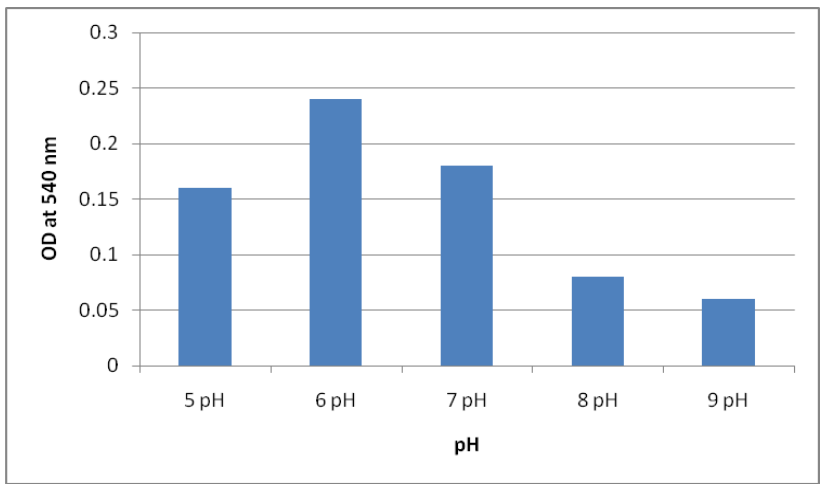

Figure 4: $\mathrm{pH}$ optimization of biofilm production

The results optimization of $\mathrm{pH}$ and temperature for the formation of biofilms are denoted in figure 3 and figure 4 respectively. Figure 3 indicates that biofilm production is maximum at $35^{\circ} \mathrm{C}$ and a minimum at $20^{\circ} \mathrm{C}$. At $30^{\circ} \mathrm{C}$, it is moderate. This indicates that the biofilm formed at $35^{\circ} \mathrm{C}$ is thicker and is found to be stronger biofilm than compared to other temperatures [31].

Figure 4 indicates the biofilm production at different $\mathrm{pH}$. It is found from the figure 4 , the organism grows and form biofilms at different $\mathrm{pH}$ of $5,6,7,8 \& 9$ but the biofilm production is found to be maximum at $\mathrm{pH} 6$ or almost neutral $\mathrm{pH} \&$ is moderate at $\mathrm{pH} 5 \& 7$ and weak biofilms are formed at pH $8 \& 9$ [31].

\section{E. Analysis of reduction of hexavalent chromium}

An initial concentration of $500 \mathrm{mg} / \mathrm{lt}$ of hexavalent chromium were prepared by dissolving $1.417 \mathrm{gm}$ of $\mathrm{K}_{2} \mathrm{Cr}_{2} \mathrm{O}_{7}$ in distilled water. The reduction process was carried out by using the Diphenyl Carbazide assay method. 


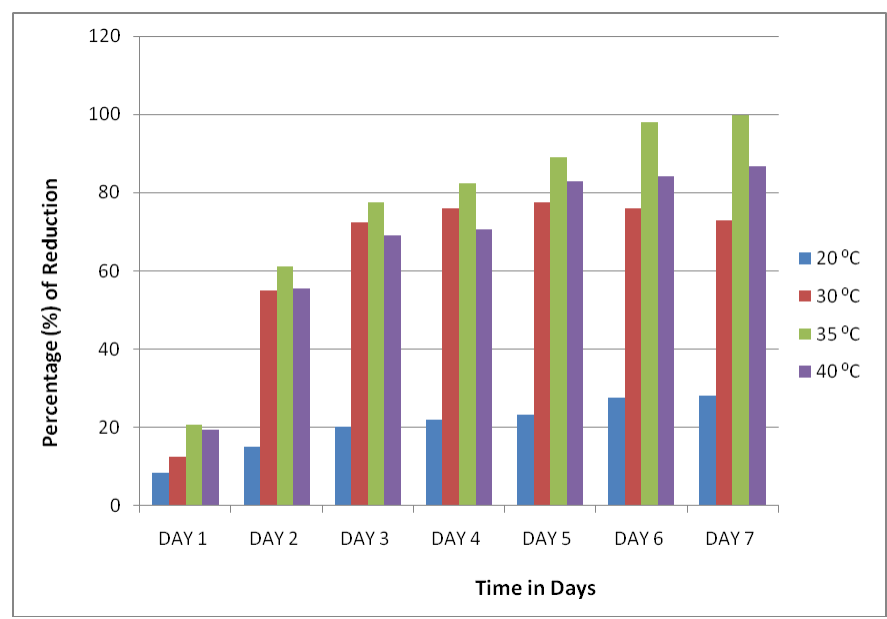

Temperature optimization

The reduction of the initial concentration of $500 \mathrm{mg} / \mathrm{lt}$ hexavalent chromium was found in different temperatures from $20^{\circ} \mathrm{C}-40^{\circ} \mathrm{C}$. The reduction started after 24 hours and consequently increased till day 7 , at temperature $20^{\circ} \mathrm{C}$ the reduction was maximum of $28 \%$ on day 7 , at temperature $30^{\circ} \mathrm{C}$ the reduction was maximum of $77.4 \%$ on day 5 , at temperature $35^{\circ} \mathrm{C}$ the reduction was maximum of $99.8 \%$ on day 7 , and at the temperature of $40^{\circ} \mathrm{C}$ the reduction was maximum of $87 \%$ on day 7 . At temperature $35^{\circ} \mathrm{C}$ the organism shows a maximum amount of reduction this proves to be a favorable condition for the reduction process.

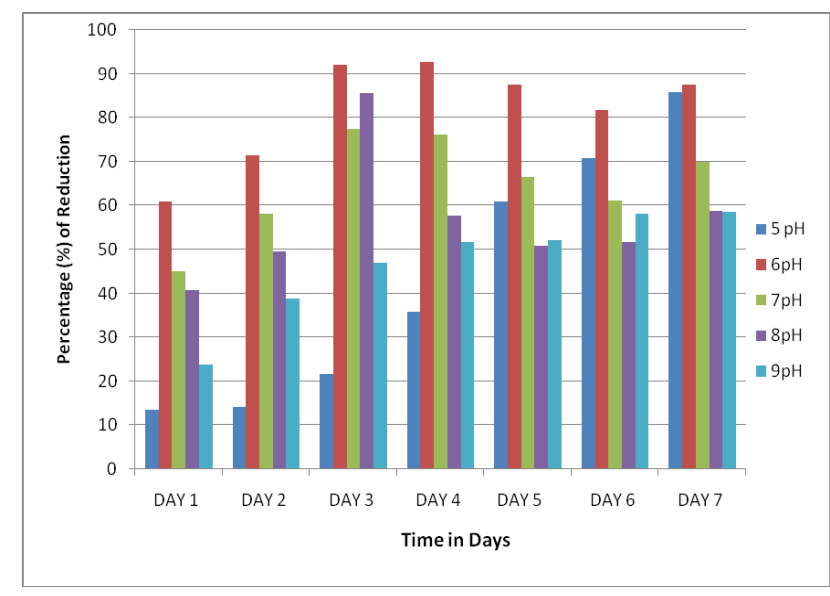

pH optimization

The reduction of the initial concentration of $500 \mathrm{mg} / \mathrm{lt}$ of Hexavalent Chromium was found at different $\mathrm{pH}$ from $5 \mathrm{pH}-9$ $\mathrm{pH}$. The reduction started after 24 hours and consequently increased till day 7, $5 \mathrm{pH}$ was maximum on day 7 of $86 \%, 6$ $\mathrm{pH}$ was maximum on day 4 of $93 \%, 7 \mathrm{pH}$ was maximum on day 4 of $76.1 \%, 8 \mathrm{pH}$ was maximum on day 3 of $86 \%$, and 9 $\mathrm{pH}$ was maximum on day 7 of $60 \%$. At $\mathrm{pH} 6$ the organism showed the maximum amount of reduction which indicates $\mathrm{pH}$ 6 is a favorable condition for the reduction process.

\section{IDENTIFICATION OF THE ORGANISM}

The isolate which was able to form strong biofilm and maximum reduction was further identified by using 16srRNA technology. The organism is identified as Bacillus Species and has $99 \%$ homology with other Bacillus strains.

\section{CONCLUSION}

The application of biofilms mainly includes the removal of toxic elements from environment. The specific secondary metabolites and the gain of robustness were produced by the bacteria in the biofilm. Biofilms provide huge microbial mass which helps in the treatment of the toxic wastes. Biofilms can be developed in both aerobic and anaerobic zones. The intrinsic properties of the biofilms vary with the environmental conditions. Biofilm treatment varies with influent characteristics and nutrient uptake. Biofilm study is still under the infancy. It acts as a friend in bioremediation and considered as a foe in the biomedical field. But very less information is obtained till now. The stability and growth of biofilm has yet to be analyzed. The enzymes produced extracellular decomposed carbohydrates, proteins and organic phosphates which in turn help in reduction of environmental contaminants found in the ecosystem. The interaction among the different organisms also responds in activating the extracellular enzymes helpful in degradation and balancing the ecosystem.

The major disadvantage of biofilms include high corrosiveness, and lack of machine stability. Biodispersants are designed to ensure that microorganisms are dispersed into the process water. They are effective in performing a function using a multiple mechanisms and are treated as a substitute to a biocide. Biofilms also are accountable for a huge variety of nonsocial infections. It includes the surfaces of medical devices, abrasion dressings, and other devices.

Colony biofilms have been used in determining antibioticresistance and to study the viability of the cells. The tube assay method is used to determine the qualitative assessment of biofilm. The microtiter plate enables researchers to quickly analyze attachment of many bacterial strains or growth circumstances in the experiment before the performance of the labor-intensive microscopic qualification. Bacillus species gram positive bacteria isolate from tannery effluent used in the reduction process is found to be very efficient in reducing $93 \%$ of $500 \mathrm{mg} / \mathrm{lt}$ of hexavalent chromium at $\mathrm{pH} 6$ and temperature at $35^{\circ} \mathrm{C}$. This organism is found to be very efficient in maximum reduction of hexavalent chromium without any amendments at natural conditions. So this organism can be used in future studies in treatment of chromium containing waste water.

\section{REFERENCE}

[1] D Lopez et al., "Biofilms", Cold Spring Harb Perspectives in biology, vol. 2(7), 2010. 


\section{International Journal of Engineering Applied Sciences and Technology, 2020 \\ Vol. 5, Issue 5, ISSN No. 2455-2143, Pages 198-202 \\ Published Online September 2020 in IJEAST (http://www.ijeast.com)}

[2] $\mathrm{T}$ Bjarnsholt et al., "Antibiotic Resistance of Antimicrobial Biofilms", International Journal of antimicrobial agents, vol. 35(4), pp. 322-332, 2010

[3] J Costerton et al., "Microbial Biofilms", Annual Review of Microbiology, vol. 49, pp. 711-745, 1995.

[4] P Stoodley et al., “ Biofilms As Complex Differentiated Communities”, Annual Review of Microbiology, vol. 56, pp. 187-209, 2002

[5] Z Zakaria et al., "Hexavalent Chromium Reduction by Acinetobacter haemolyticus isolated from heavy metal contaminated wastewater", Journal of Hazardous Materials, vol. 146, pp. 30-38, 2006

[6] J Chandra et al., "Biofilm formation by the Fungal pathogen Candida albicans: development, architecture, and drug resistance", Journal of Bacteriology, vol. 183(18), pp. 5385-5394, 2001

[7] A Clutterbucket al., "Evaluating antibiotics for use in medicine using a poloxamer biofilm model", Annals of Clinical Microbiology and Antimicrobials, vol. 6, 2007.

[8] R Roelandts, "The history of phototherapy: something new under the sun?" Journal of the American Academy of Dermatology, vol. 46(6), pp. 926-930, 2002.

[9] H Flemming and J Wingender, "Relevance of microbial extracellular polymeric substances (EPSs)-part I: structural and ecological aspects", vol. 43(6), pp. 1-8, 2001.

[10] C Mayer et al., "The role of intermolecular interactions: studies on model systems for bacterial biofilms", vol. 26(1), pp. 3-16, 1999.

[11] I Sutherland, "Biofilm exopolysaccharides: a strong and sticky framework", Microbiology, vol. 147(1), pp. 3-9, 2001.

[12] I Sutherland, "The biofilm matrix-an immobilized but dynamic microbial environment", vol. 9(5), pp. 22-227, 2001.

[13] I Sutherland, "Exopolysaccharides in biofilms, flocs, and related structures", Water Science and Technology, vol. 43(6), pp. 77-86.

[14] B Biradar and P Devi, "Quorum sensing in plaque biofilms: challenges and prospects", Journal of Contemporary Dental Practice, vol. 12(6), pp. 479-485, 2011.

[15] R M Donlan, "Biofilms: microbial life on surfaces", Emerging Infectious Diseases, vol. 8(9), pp. 881-890, 2002.

[16] R M Donlan and J W Costerton, "Biofilms: survival mechanisms of clinically relevant microorganisms", Clinical Microbiology Reviews, vol. 15(2), pp. 167-193, 2002.

[17] C W Waters and B L Bassler, "Quorum sensing: cell-tocell communication in bacteria", Annual Review of Cell and Development Biology, vol. 21, pp. 319-346, 2005.
[18] N C Reading and V Sperandio, "Quorum sensing: the many languages of bacteria", FEMS Microbiology Letters, vol. 254(1), pp. 1-11, 2006.

[19] B R Boles and A R Horswill, "Agri-mediated dispersal of Staphylococcus aureus biofilms", PLoS Pathogens, vol. 4(4), 2008.

[20] M Narayani and K Shetty, "Chromium-Resistant Bacteria and their Environmental Condition for Hexavalent Chromium Removal", Critical Reviews in Environmental Science and Technology, vol. 43(9), pp. 955-1009, 2012.

[21] C Wilson et al., "Quantitative and Qualitative Assessment Methods for Biofilm Growth", HHS Public Access, vol. 6(4), 2017.

[22] B Gottenbos et al., "Initial adhesion and surface growth of Pseudomonas aeruginosa on negatively and positively charged poly(methacrylates)", Journal of Materials Science, vol. 10, pp. 853-855, 1999.

[23] S Jamwal et al., "Enhancing the Hexavalent Chromium Bioremediation Potential of Acinetobacter junii VITSUKMW2 using Statistical Design Experiments", Journal of Microbiology and Biotechnology, vol. 22(12), pp. 1767-1775, 2012.

[24] J mater et al., "Structural and Functional Characteristics of Bacterial Biofilms in Fluid Processing Operations", Journal of Dairy Science, vol. 81, pp. 2760-2764, 1998.

[25] M Pazos et al., "Removal of $\mathrm{Cr}(\mathrm{VI})$ from Aqueous Solutions by a Bacterial Biofilms Supported on Zeolite: Optimisation of the Operational Conditions and Scale-Up of the Bioreactor", Chemical Engineering Technology, vol. 33(12), pp. 2008-2014, 2008.

[26] J Merritt et al., "Growing and Analyzing Static Biofilms", HHS Public Access, vol. 1, 2015.

[27] R Palmer, "Supragingival and Subgingival Plaque: Paradigmbiofilms", Compendium of Continuing Education in Dentistry, 2010.

[28] L Pratt et al., "Genetic approaches to study of Biofilms", Methods in Enzymology, vol. 310, pp. 91-109, 1999.

[29] K Sawyer and W Hermanowicz, "Detachment of biofilm bacteria due to variations in nutrient supply", Water Science and Technology, vol. 37, pp. 211-214, 1998.

[30] Y Madhumala et al., "Reduction of Hexavalent Chromium using Biofilm Forming Isolates", International Journal of Technical Innovation in Modern Engineering \& Science, vol. 4(11), pp. 2455-2585, 2018.

[31] Madhumala Y et al., "Comparative Study of Bioreduction of Water Containing Hexavalent Chromium Using Biofilm Forming and Non-Biofilm Forming Bacteria", International Journal of Advanced Research Methodology in Engineering \& Technology, vol. 1(2), pp. 41-44, 2017. 